Available online at GSC Online Press Directory

GSC Biological and Pharmaceutical Sciences

e-ISSN: 2581-3250, CODEN (USA): GBPSC2

Journal homepage: https://www.gsconlinepress.com/journals/gscbps

(RESEARCH ARTICLE)

\title{
Boiling increase antioxidant activity, total phenolic content and total flavonoid content in Plectranthus amboinicus leaves
}

\author{
Muhamad Shamsul ${ }^{*}$ and Mat Ali Siti Fatimah Zahrah \\ Faculty of Agro Based Industry, Universiti Malaysia Kelantan, Locked Bag No 100, 17600 Jeli, Kelantan, Malaysia.
}

Publication history: Received on 13 February 2019; revised on 28 February 2019; accepted on 05 March 2019

Article DOI: https://doi.org/10.30574/gscbps.2019.6.3.0023

\begin{abstract}
The effect of boiling on antioxidant activity, total phenolic content (TPC) and total flavonoid content (TFC) in the ethanol extracts from Plectranthus amboinicus leaves were studied. The dried leaves were boiled in water for 0 (control), 30, 60, 90 and 120 minutes, then extracted with ethanol to produce ethanol extracts. The ethanol extracts were subjected to three antioxidant assays, i.e., 2, 2-diphenyl-1-picrylhydrazyl (DPPH), 2, 2'-azino-bis (3-ethylbenzothiazoline-6sulphonic acid) (ABTS) and ferric reducing antioxidant power (FRAP). TPC and TFC in extracts were determined by Folin-Ciocalteu assay and aluminium chloride colorimetric assay, respectively. The results of DPPH, ABTS and FRAP assays indicated that the antioxidant of extracts were significantly $(\mathrm{p}<0.05)$ more potent than the control and also increased when the boiling time was increased. Furthermore, TPC and TFC in extracts from boiled samples were significantly $(\mathrm{p}<0.05)$ higher than the control and correlated with antioxidant activity. This study revealed that boiling of $P$. amboinicus leaves were increased its antioxidant activity, TPC and TFC as determine in ethanol extracts, and suggested that boiling can be used as a method for enhancing antioxidant activity of P. amboinicus.
\end{abstract}

Keywords: Plectranthus amboinicus; Antioxidant; Total phenolic content; Total flavonoid content

\section{Introduction}

Fats and oils are important substances during food processing and also use as ingredients in a variety of foods. They act as heat transfer medium, emulsifier, texture controller, flavor enhancer and nutritive substance [1-4]. However, autoxidation of fats and oils is one of the limiting factors in a food product's shelf life as noticeable by rancid odour and flavour, but can be prevented by using antioxidant agents [2-3]. In current food industry, synthetic antioxidant agents such as butylated hydroxyanisole, butylated hydroxytoluene and tertiary-butyl hydroquinone regularly used as antioxidant food preservative [5]. Unfortunately, all of these agents have long been linked to several adverse reaction such as allergy, asthma, dermatitis, flushing, headache, stomach problems, joint pain and weight gain [6-7]. Owing to good reputation, naturally occurring antioxidants are gaining more attention and choice of consumer for substitute the synthetic antioxidants [8-9].

Plectranthus amboinicus (Lamiaceae) or Indian borage is a soft-stem plant with a strong oregano-like minty aroma and flavor mainly cultivated and used in traditional medicine or culinary purposes by in tropical and subtropical regions such as India, Southeast Asian (Malaysia, Indonesia, Thailand), China, Taiwan, West Asia (Egypt) and United States of America (Hawaii) [10]. This plant is propagated by stem cutting and grows well in drained soil with enough water. Height of plant can reach up to 1 meter or more after five months [11]. In culinary, fresh or dried leaves were used as a food additive to enhance flavour and aroma in marinate meats, fritter, wine and beer as well as to increase a shelf life of food [12-14].

\footnotetext{
${ }^{*}$ Corresponding author

E-mail address: shamsul.m@umk.edu.my
}

Copyright (C) 2019 Author(s) retain the copyright of this article. This article is published under the terms of the Creative Commons Attribution Liscense 4.0. 
P. amboinicus is one of the most documented and cited species in the family Lamiaceae for its biological activities including antioxidant properties of stem and leaf; which contributes by the non-volatile secondary metabolites from the class of phenolics; and specifically from groups of phenolic acid and flavonoids [10]. The phenolic acids were included caffeic acid, rosmarinic acid, gallic acid, $\rho$-coumaric acid, salvianolic acid A and shimobashiric acid; whereas the flavonoids was chrysoeriol, cirsimaritin, eriodictyol, luteolin, rutin, salvigenin, thymoquinone and quercetin [15]

Currently, three species of the family of the Lamiaceae, i.e., rosemary, sage and oregano have been successfully developed and commercial as natural antioxidant for uses as food preservative [16-17]. The companies that produce a proprietary antioxidant food preservative from these plants are included Naturex, Kalsec, Frutarom and Kemin; and these products are relying on the presence of rosmarinic acid, canosic acid and diterpene phenol [18]. Although, $P$. amboinicus is from the same family and many studied on its antioxidant activity and phytochemical, the potential of this plant for antioxidant preservative was not yet explored. This may to factor of an extracts that less potent antioxidant activity when compared to rosemary, sage or oregano [18-20]. For example, by DPPH assays, the IC 50 of rosemary, sage and oregano were below than $10 \mu \mathrm{g} / \mathrm{l}$ but for P. amboinicus, the IC 50 was above $80 \mu \mathrm{g} / \mathrm{ml}$ [21].

Many studies were reported that a thermal treatment of some plants were increased their antioxidant activity [22-25] and can be used as a tool for increasing antioxidant activity [23]. However, the effect of thermal treatment on antioxidant activity of this plant is scarce [26]. Thus, this studied was conducted to determine the effect of thermal treatment on antioxidant in leaves of $P$. amboinicus.

\section{Material and methods}

\subsection{Sample of $P$. amboinicus leaves}

Mixture of mature and young leaves of Indian borage was collected from herbal garden at Universiti Malaysia Kelantan, Malaysia and chopped. Chopped leaves were dried in electrical oven at $65^{\circ} \mathrm{C}$ for 72 hours, then kept at $-20^{\circ} \mathrm{C}$.

\subsection{Thermal treatment of leaves by boiling in water}

Five conical flasks containing $200 \mathrm{ml}$ of deionized water were filled with $50 \mathrm{~g}$ of powdered leaves sample. All conical flasks were initially sonicated for 30 minutes in ultrasonic bath. One flask was served as control ( 0 minute) by kept at room temperature; and other flasks were further continuously boiled at $100{ }^{\circ} \mathrm{C}$ in a water bath for $30,60,90$ and 120 minutes, respectively. Water was decanted and leaves biomasses were dried in fume hood for 24 hour at room temperature and used for further extraction with ethanol.

\subsection{Extraction of boiled leaves biomass with ethanol and yield (\%)}

Unboiled and boiled leaves were soaked with $100 \mathrm{ml}$ ethanol and sonicated using ultrasonic water bath for 30 minutes and filtered to obtain ethanol extracts. The ethanol from the extracts were removed under reduced pressure using rotary evaporator. The percentage of extraction was calculated by dividing the yield of extract with the weight of dried raw material and times with 100 . All extracts were kept at $-20^{\circ} \mathrm{C}$ until used for assays.

\subsection{Antioxidant assay}

\subsubsection{DPPH free radical scavenging assay}

DPPH (2, 2-diphenyl-1-picrylhydrazyl) free radical scavenging activity of extracts were determined using the method as previously described [26]. Briefly, $2 \mathrm{ml} \mathrm{0.004 \%} \mathrm{(w/v)} \mathrm{DPPH} \mathrm{solution} \mathrm{was} \mathrm{mixed} \mathrm{with} 2$ ml of samples solution in $100 \%$ ethanol at concentration from $12.5 \mu \mathrm{g} / \mathrm{ml}$ to $200 \mu \mathrm{g} / \mathrm{ml}$ and allowed to react in a dark for 30 minutes. Then, optical density (OD) of mixture was read at with spectrophotometer at $517 \mathrm{~nm}$. Positive control, ascorbic acid was used at concentrations from $0.3125 \mu \mathrm{g} / \mathrm{ml}$ to $10 \mu \mathrm{g} / \mathrm{ml}$. A DPPH free radical scavenging activity of sample was calculated as follows: [ $\left.\left(\mathrm{OD}_{\text {control }}-\mathrm{OD}_{\text {sample }}\right) / \mathrm{OD}_{\text {control }}\right] \mathrm{x} 100 \%$. The $\mathrm{IC}_{50}$ value of sample, i.e., an amount of antioxidant necessary to decrease the initial DPPH concentration by $50 \%$ was calculated from the graph concentration of sample versus \% of DPPH free radical scavenging activity.

\subsubsection{ABTS free radical scavenging assay}

The ABTS (2, 2'-azino-bis (3-ethylbenzothiazoline-6-sulphonic acid) assay was followed as described by Dhanani et al. [27]. Fresh solution of ABTS was prepared by mixed $10 \mathrm{ml} 4.9 \mathrm{mM}$ potassium persulfate with $10 \mathrm{ml} 14 \mathrm{mM}$ ABTS solution and incubated in the dark at room temperature for 16 hours. Before used for assay, the ABTS working solution was prepared by diluted with methanol to achieve initial absorbance of $0.70 \pm 0.02$ at $734 \mathrm{~nm}$. For assay, $950 \mu \mathrm{l}$ ABTS 
working solution was mixed with $50 \mu \mathrm{L}$ of sample and were vortexed for 10 seconds. The reaction was further incubated for 6 minutes and the optical density (OD) was recorded at $734 \mathrm{~nm}$ using spectrophotometer. ABTS working solution without sample was used as control and Trolox was used as positive control. The percentage inhibition was calculated according to formula: $\left[\left(\mathrm{OD}_{\text {control }}-\mathrm{OD}_{\text {sample }}\right) / \mathrm{OD}_{\text {control }}\right] \times 100 \%$. The amount of antioxidant necessary to decrease the initial ABTS concentration by $50 \%$ ( $\mathrm{IC}_{50}$ value) was calculated from the graph concentration of sample versus $\%$ of ABTS free radical scavenging activity. Low value of $\mathrm{IC}_{50}$ indicate strong free radical scavenging activity of a sample.

\subsubsection{Ferric reducing antioxidant power assay}

The FRAP (Ferric reducing antioxidant power) assay is a measurement for ability of extract to reduce ferric ions. In this experiment, FRAP assay was determined according to the method previously described by Benzie and Strain in 1996 [28]. The stock solution FRAP was prepared included $300 \mathrm{mM}$ acetate buffer ( $3.1 \mathrm{~g}$ sodium acetate trihydrate and $16 \mathrm{ml}$ acetic acid) for $\mathrm{pH} 3.6,10 \mathrm{mM} \mathrm{2,} \mathrm{4,} \mathrm{6-tripyridyl-s-triazine} \mathrm{solution} \mathrm{in} 40 \mathrm{mM} \mathrm{HCL}$, and $20 \mathrm{mM}$ iron (III) chloride hexahydrate. The fresh working solution was prepared by mixing $25 \mathrm{ml} \mathrm{FeCl} 3.6 \mathrm{H} 20$ solution and then warmed at 37 ${ }^{\circ} \mathrm{C}$ before using it. $150 \mu \mathrm{l}$ of plant extracts was allowed to react with $2850 \mu \mathrm{l}$ of the FRAP solution by incubating in the dark condition for 30 minutes. Reduced coloured product (ferrous tripyridyltriazine complex) were read using UV-VIS spectrophotometer at $593 \mathrm{~nm}$. Trolox in various concentrations $(3.125-100 \mu \mathrm{g} / \mathrm{ml})$ was used for the preparation of the standard calibration curve. The FRAP values were expressed as mg trolox equivalent per gram of extract (mg $\mathrm{TE} /$ gram of extract). The means of three independent experiments were calculated and presented as mean \pm standard deviation (SD). High value of FRAP (mg TE/g extract) of extract shows strong antioxidant activity of a sample.

\subsection{Total phenolic content (TPC)}

Total phenolic content (TPC) in extracts was determined by Folin-Ciocalteu assay with slight modification [26]. Gallic acid was used as the standard curve of the range of $6.125 \mu \mathrm{g} / \mathrm{ml}$ to $100 \mu \mathrm{g} / \mathrm{ml}$. A volume of $0.5 \mathrm{ml}$ gallic acid or extracts were mixed with $1.5 \mathrm{ml}$ of $10 \%(\mathrm{v} / \mathrm{v})$ Folin- Ciocalteu reagent and incubated at room temperature for 5 minutes. Then, $2 \mathrm{ml} 7.5 \%(\mathrm{w} / \mathrm{v}$ ) of sodium carbonate was added into the mixture and allowed to react in the dark for 60 minutes. The optical density of the reactant was read at $765 \mathrm{~nm}$ using spectrophotometer. The TPC in samples were expressed as $\mathrm{mg}$ gallic acid equivalent per $\mathrm{g}$ of extract (mg GAE/g extract).

\subsection{Total flavonoid content (TFC) assay}

The total flavonoid contents of extract samples determined using aluminium chloride colorimetric assay [29]. Briefly, 1 $\mathrm{mg}$ of plant extract was dissolved in $1 \mathrm{ml}$ ethanol extraction to achieve concentration $1 \mathrm{mg} / \mathrm{ml}$ for each extract. In a 10 $\mathrm{ml}$ test tube, $0.3 \mathrm{ml}$ extracts sample and $3.4 \mathrm{ml}$ of $30 \%$ methanol, $150 \mu \mathrm{l}$ of $0.5 \mathrm{M}$ sodium nitrite solution and $150 \mu \mathrm{l}$ of $0.3 \mathrm{M}$ aluminium chloride solution was mixed. After incubated for 5 minutes, $1 \mathrm{ml}$ of $1 \mathrm{M}$ natrium hydroxide solution was added. The absorbance reading was recorded using UV-VIS spectrophotometer at $506 \mathrm{~nm}$ against blank which containing an equal amount of methanol in place of extracts sample. Quercetin was used for standard calibration curve for total flavonoid content in samples that were expressed as mg quercetin equivalent per gram sample (mg QE/g sample).

\subsection{Statistical analysis}

All assays were conducted in triplicated and repeated for the three independent experiments. Data were presented as means \pm standard deviations. Student's t-test was applied to compare the antioxidant activity and TPC between unboiled (control) and boiled ethanol extracts. The $\mathrm{p} \leq 0.05$ was considered as significance.

\section{Results and discussion}

In this current study, the effect of thermal by boiling in leaves of P. amboinicus on percentage yield, antioxidant activity, total phenolic and flavonoid content were determined. Figure 1 shows the percentage yield of extract per dry weight of sample. The yield of extract for boiled samples at 30, 60, 90 and 120 minutes were increased significantly $(\mathrm{p}<0.05)$ compared to control at $78 \%, 83 \%, 87 \%$ and $131 \%$, respectively. These results indicated that longer boiling time was increase the yield of extract. Several researchers were reported that thermal treatments such as boiling, autoclaving and baking increased the yield of extract from plant samples [22, 30-31]. High temperature treatments on plant can cause the formation of large cell micropore due to deformation of the structure of cell walls and change porosity and resulting in loss selective permeability [32-33]. 


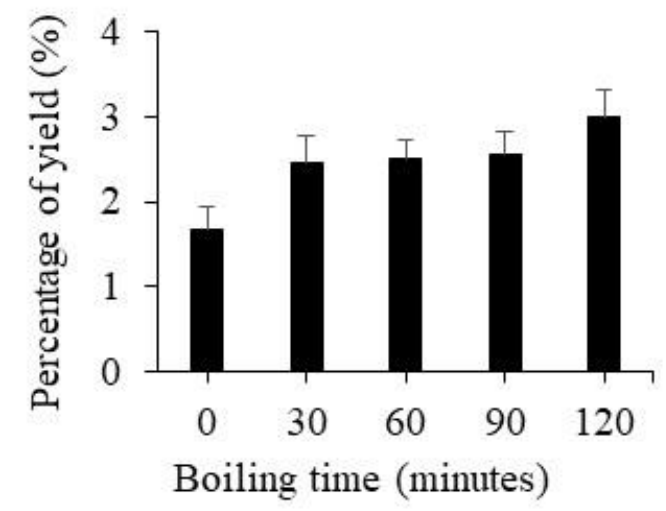

Figure 1 Extraction yield (\%) of ethanol extracts from P. amboinicus leaves after boiling

Figure 2 was shown the results for free radicals scavenging activity (DPPH and ABTS assay) and reducing power (FRAP assay) of the ethanol extracts from unboiled ( 0 minute) and boiled for 30,60 and 120 minutes of $P$. amboinicus leaves. The ethanol extract from unboiled leaves was served as a control for comparison. In general, longer boiling time was increased antioxidant activities of ethanol extracts as indicated by decreasing of IC50 values in DPPH and ABTS assay, and increasing ability of extract to reduce ferric ions in FRAP assay. The IC 50 value of the DPPH assay for boiled extracts at 30,60, 90 and 120 minutes were decreased significantly $(\mathrm{p}<0.05)$ compared to control $(92.85 \pm 7.07 \mu \mathrm{g} / \mathrm{ml})$ at 4.72 $\%(88.46 \pm 1.18 \mu \mathrm{g} / \mathrm{ml}), 13.94 \%(79.91 \pm 3.37 \mu \mathrm{g} / \mathrm{ml}), 27.16 \%(67.63 \pm 4.09 \mu \mathrm{g} / \mathrm{ml})$ and $51.05 \%(45.43 \pm 2.33 \mu \mathrm{g} / \mathrm{ml})$, respectively. For the ABTS assay, the result shows the IC50 value of boiled extract at 30, 60, 90 and 120 minutes were also decreased significantly ( $<<0.05)$ compared to control $(86.68 \pm 1.41 \mu \mathrm{g} / \mathrm{ml})$ at $6.91 \%(80.69 \pm 0.92 \mu \mathrm{g} / \mathrm{ml}), 20.75$ $\%(68.26 \pm 2.71 \mu \mathrm{g} / \mathrm{ml}), 34.32 \%(56.93 \pm 5.24 \mu \mathrm{g} / \mathrm{ml})$ and $58.62 \%$ (35.87 $\pm 0.799 \mu \mathrm{g} / \mathrm{ml})$, respectively. The IC 50 for ascorbic acid as determined by DPPH and ABTS were $1.83 \pm 0.17 \mu \mathrm{g} / \mathrm{ml}$ and $4.48 \pm 1.27 \mu \mathrm{g} / \mathrm{ml}$, respectively. These values were within the range as reported [34-36].

In the FRAP assay, the antioxidant activity of boiled samples were increased significantly ( $\mathrm{p} \leq 0.05)$ when compared with the unboiled sample. In comparison with unboiled (18.67 $\pm 0.06 \mathrm{mg}$ TE/g extract) sample, the antioxidant activity of the extract for boiled samples at 30, 60, 90 and 120 minutes were increased by $4.71 \%$ (19.55 $\pm 0.35 \mathrm{mg}$ TE/g extract), $46.52 \%$ (27.41 $\pm 0.73 \mathrm{mg} \mathrm{TE} / \mathrm{g}$ extract), $152.22 \%$ (48.08 $\pm 3.54 \mathrm{mg}$ TE/g extract) and 238.50 \% (63.32 $\pm 5.70 \mathrm{mg} \mathrm{TE} / \mathrm{g}$ extract), respectively. This result was in agreement with our previous reported study, but at a lower temperature, i.e., $95^{\circ} \mathrm{C}[26]$.
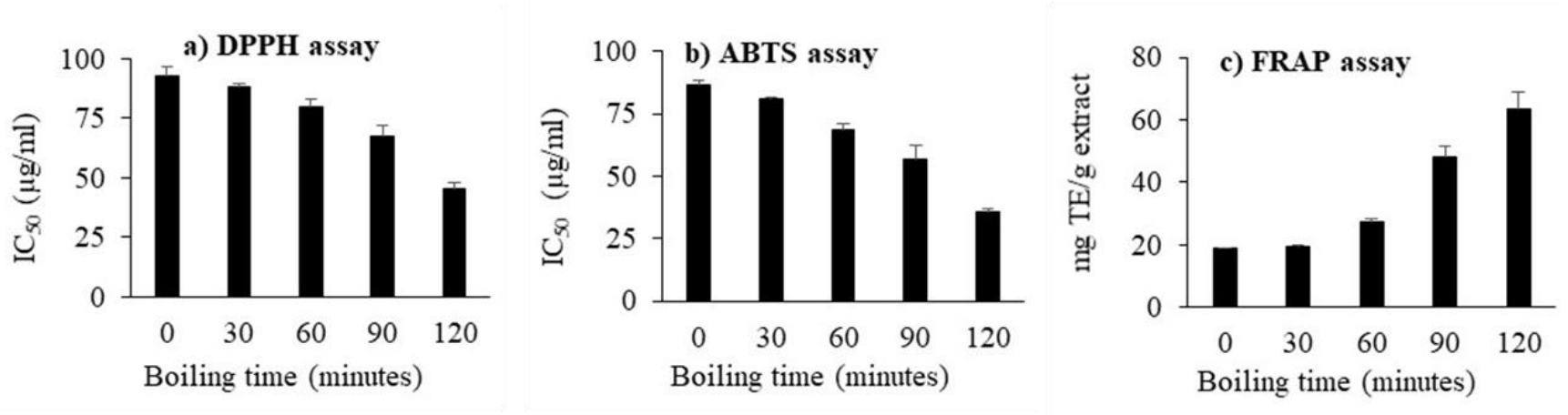

Figure 2 Antioxidant activity of ethanol extracts from $P$. amboinicus leaves were determined by DPPH, ABTS and FRAP assay. The leaves were boiled at $100{ }^{\circ} \mathrm{C}$ and extracted with ethanol. All data were presented as mean \pm S.D.

In this study, the TPC (Figure 3a) of extracts from boiled sample for 30, 60, 90 and 120 minutes was $13.09 \%, 27.65 \%$, $47.51 \%$ and $67.13 \%$ were higher $(\mathrm{p} \leq 0.05)$ than unboiled samples. The similar pattern was also recorded for the amount of TFC (Figure 3b). The TFC (Figure 3b) of extracts from boiled sample for 30, 60, 90 and 120 minutes was 42.85 $\%, 53.89 \%, 75.99 \%$ and $99.06 \%$ were significantly higher ( $\leq$ 0.05) compared to unboiled samples. The correlation between antioxidant activity with TPC and TFC were analyzed. The increased of TPC over the boiling time were strongly correlated with the antioxidant activity when compared with DPPH assay ( $r=-0.9798)$, ABTS assay ( $r=-0.9913)$ and FRAP assay $(r=0.9751)$. Also, the increment of TFC over the boiling time were strongly correlated with the antioxidant 
activity when compared with DPPH assay ( $\mathrm{r}=-0.9183)$, ABTS assay $(\mathrm{r}=-0.9404)$ and FRAP assay $(\mathrm{r}=0.8963)$. This analysis indicated that antioxidant activity in boiling extracts was associated with TPC and TFC. The increment of antioxidant activity, TPC and TPC were in agreements with several authors when they worked on their plant samples after thermal treatment [24-25, 37-40].
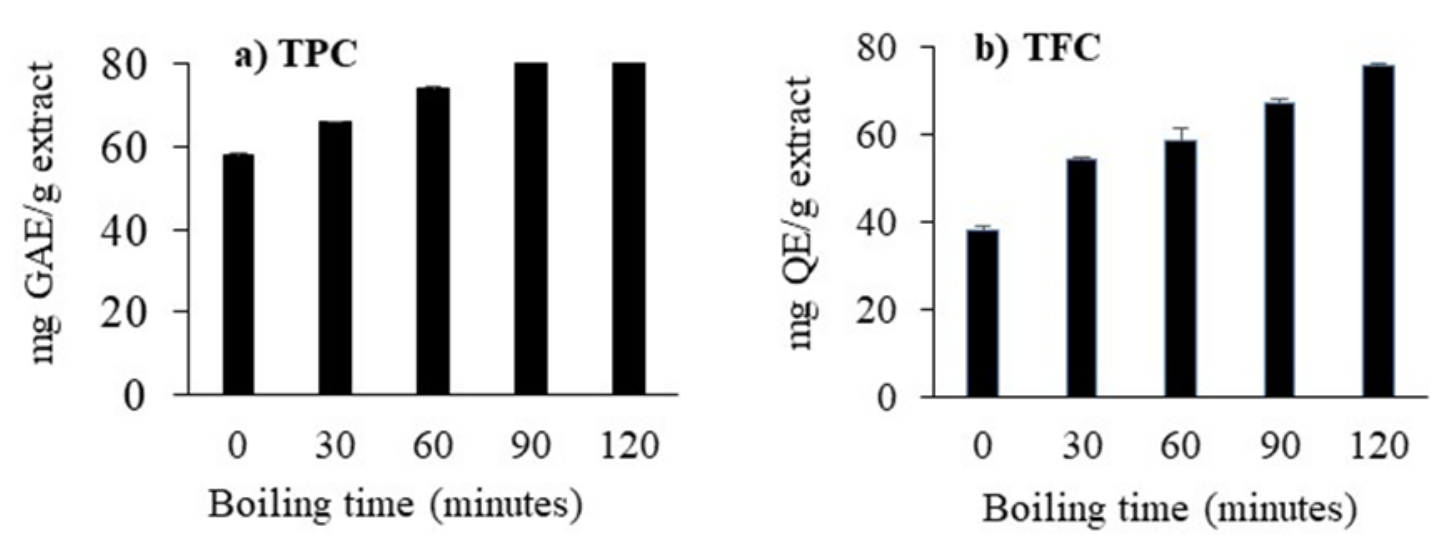

Figure 3 Total phenolic content (TPC) and total flavonoid content (TFC) of ethanol extracts from leaves of $P$. amboinicus leaves. Data were presented as mean \pm S.D.

The reason for increments of antioxidant activity, TPC and TFC after thermal treatment can be explained by the two mechanisms. The first is due to an inactivation the polyphenol oxidase enzymes leading to inhibition of polyphenolics degradation [25,41], and the second is the cause of a Maillard reaction occur during thermal treatment that decompose a phenolic substances and produce new products with more potent antioxidant activity [40].

\section{Conclusion}

The results of the study demonstrate that thermal treatment by boiling of $P$. amboinicus leaves was significantly increased the antioxidant activity as determined in ethanol extracts. Boiling also increased the percentage of extraction yield, TPC and TFC. These results also warrants for further investigation on application of P. amboinicus leaves as food preservative with antioxidant property.

\section{Compliance with ethical standards}

\section{Acknowledgment}

This work was funded by the Ministry of Higher Education, Malaysia and the research grant number was R/FRGS/A07.00/00663A/001/2014/000173.

\section{Disclosure of conflict of interest}

We have no conflict of interest.

\section{References}

[1] Bayarri S, Taylor AJ and Hort J. (2006). The role of fat in flavor perception: effect of partition and viscosity in model emulsions. Journal of Agricultural and Food Chemistry, 54(23), 8862-8868.

[2] Frankel EN. (1996). Antioxidants in lipid foods and their impact on food quality. Food Chemistry, 57(1), 51-55.

[3] Frankel EN. (2014). Lipid oxidation. Elsevier.

[4] Taghvaei M and Jafari SM. (2015). Application and stability of natural antioxidants in edible oils in order to substitute synthetic additives. Journal of Food Science and Technology, 52(3), 1272-1282.

[5] Al-Shabib NA, Khan JM, Ali MS, Al-Lohedan HA, Khan MS, Al-Senaidy AM and Shamsi MB. (2017). Exploring the mode of binding between food additive "butylated hydroxytoluene (BHT)" and human serum albumin: Spectroscopic as well as molecular docking study. Journal of Molecular Liquids, 230, 557-564. 
[6] Clayson DB, Iverson F, Nera E, Lok E, Rogers C, Rodrigues C, Page D and Karpinski K. (1986). Histopathological and radioautographical studies on the forestomach of F344 rats treated with butylated hydroxyanisole and related chemicals. Food and Chemical Toxicology, 24(10-11), 1171-1182.

[7] Simon RA. (2003). Adverse reactions to food additives. Current Allergy and Asthma Reports, 3(1), 62-66.

[8] Embuscado ME. (2015). Spices and herbs: Natural sources of antioxidants-a mini review. Journal of Functional Foods, 18, 811-819.

[9] McCarthy TL, Kerry JP, Kerry JF, Lynch PB and Buckley DJ. (2001). Evaluation of the antioxidant potential of natural food/plant extracts as compared with synthetic antioxidants and vitamin E in raw and cooked pork patties. Meat Science, 58(1), 45-52.

[10] Arumugam G, Swamy MK and Sinniah UR. (2016). Plectranthus amboinicus (Lour.) Spreng: botanical, phytochemical, pharmacological and nutritional significance. Molecules, 21(4):369.

[11] Staples GW and Kristiansen MS. (1999). Ethnic Culinary Herbs: A Guide to Identification and Cultivation in Hawaii; University of Hawaii Press: Honolulu, HI, USA.

[12] Brown D. (1997). Grenada: Isle of spices. Herbs, 22, 6-7.

[13] Lukhoba CW, Simmonds MS and Paton AJ (2006). Plectranthus: a review of ethnobotanical uses. Journal of Ethnopharmacology, 103(1), 1-24.

[14] Morton JF. (1992). Country borage (Coleus amboinicus Lour.): A potent flavoring and medicinal plant. Journal of Herbs Spices and Medicinal Plants, 1(1-2), 77-90.

[15] El-hawary SS, El-sofany RH, Abdel-Monem AR, Ashour, RS and Sleem AA. (2012). Polyphenolics content and biological activity of Plectranthus amboinicus (Lour.) spreng growing in Egypt (Lamiaceae). Pharmacognosy Journal, 4(32).

[16] Bhale SD, Xu Z, Prinyawiwatkul W, King JM and Godber JS. (2007). Oregano and rosemary extracts inhibit oxidation of long-chain n-3 fatty acids in menhaden oil. Journal of Food Science, 72, C504-C508.

[17] Fan L and Eskin NM. (2015). The use of antioxidants in the preservation of edible oils. In Handbook of Antioxidants for Food Preservation, 373-388.

[18] Capecka E, Mareczek A and Leja M. (2005). Antioxidant activity of fresh and dry herbs of some Lamiaceae species. Food chemistry, 93(2), 223-226.

[19] Erkan N, Ayranci G and Ayranci E. (2008). Antioxidant activities of rosemary (Rosmarinus Officinalis L.) extract, blackseed (Nigella sativa L.) essential oil, carnosic acid, rosmarinic acid and sesamol. Food Chemistry, 110(1), 76-82.

[20] Lu Y and Foo LY. (2001). Antioxidant activities of polyphenols from sage (Salvia officinalis). Food chemistry, 75(2), 197-202.

[21] Rai V, Pai V and Kedilaya P. (2016). A preliminary evaluation of anticancer and antioxidant potential of two traditional medicinal plants from Lamiaceae - Pogostemon heyneanus and Plectranthus amboinicus. Journal of Applied Pharmaceutical Science, 6(8), 73-78.

[22] Dent M, Dragovic-Uzelac V, Penic M, Brncic M, Bosiljkov T and Levaj B. (2013). The effect of extraction solvents, temperature and time on the composition and mass fraction of polyphenols in Dalmatian wild sage (Salvia officinalis L.) extracts. Food Technology and Biotechnology, 51(1), 84.

[23] Jeong SM, Kim SY, Kim DR, Jo SC, Nam KC, Ahn DU and Lee SC. (2004). Effect of heat treatment on the antioxidant activity of extracts from citrus peels. Journal of Agricultural and Food Chemistry, 52(11), 3389-3393.

[24] Nikousaleh A and Prakash J. (2016). Antioxidant components and properties of dry heat treated clove in different extraction solvents. Journal of Food Science and Technology, 53(4), 1993-2000.

[25] Shaimaa GA, Mahmoud MS, Mohamed MR, and Emam AA. (2016). Effect of heat treatment on phenolic and flavonoid compounds and antioxidant activities of some Egyptian sweet and chilli pepper. Natural Products Chemistry \& Research.

[26] Muhamad S and Ali SFZM. (2018). Effect of heating at $95^{\circ} \mathrm{C}$ on antioxidant activity and total phenolic content in extracts of Plectranthus amboinicus leaves. International Journal of Recent Scientific Research, 9(7), 2809628099. 
[27] Dhanani T, Shah S, Gajbhiye NA and Kumar S. (2017). Effect of extraction methods on yield, phytochemical constituents and antioxidant activity of Withania somnifera. Arabian Journal of Chemistry, 10, S1193-S1199.

[28] Benzie IF and Strain JJ (1996). The ferric reducing ability of plasma (FRAP) as a measure of "antioxidant power": the FRAP assay. Analytical biochemistry, 239(1), 70-76.

[29] Do QD, Angkawijaya AE, Tran-Nguyen PL, Huynh LH, Soetaredjo FE, Ismadji S and Ju YH. (2014). Effect of extraction solvent on total phenol content, total flavonoid content, and antioxidant activity of Limnophila aromatica. Journal of Food and Drug Analysis, 22(3), 296-302.

[30] Braga GC, Melo PS, Bergamaschi KB, Tiveron, AP, Massarioli AP and Alencar SMD. (2016). Extraction yield, antioxidant activity and phenolics from grape, mango and peanut agro-industrial by-products. Ciência Rural, 46(8), 1498-1504.

[31] Wang X, Wu Y, Chen G, Yue W, Liang Q and Wu Q. (2013). Optimisation of ultrasound assisted extraction of phenolic compounds from Sparganii rhizoma with response surface methodology. Ultrasonics sonochemistry, 20(3), 846-854.

[32] Efthymiopoulos I, Hellier P, Ladommatos N, Russo-Profili A, Eveleigh A, Aliev A and Mills-Lamptey B. (2018). Influence of solvent selection and extraction temperature on yield and composition of lipids extracted from spent coffee grounds. Industrial Crops and Products, 119, 49-56.

[33] Quinn PJ. (1988). Effects of temperature on cell membranes. Symposia of the Society for Experimental Biology, 42, 237-258.

[34] Bao Y, Qu Y, Li J, Li Y, Ren X, Maffucci KG and Zeng R. (2018). In vitro and in vivo antioxidant activities of the flowers and leaves from Paeonia rockii and identification of their antioxidant constituents by UHPLC-ESI-HRMSn via pre-column DPPH reaction. Molecules, 23(2), 392.

[35] Kiranmayi GVN. (2018). Comparative in vitro antioxidant activities of ethanolic extract, ethyl acetate extract (EAE), and hexane extracts (HE) of Tecoma gaudichaudi flowers. International Journal of Green Pharmacy, 12(01).

[36] Nahak G and Sahu RK. (2010). In vitro antioxidative acitivity of Azadirachta indica and Melia azedarach leaves by DPPH scavenging assay. Nat Sci, 8(4), 22-28

[37] Carmen POP, Rotar AM, Salanța L, Socaci S, Ranga F and Socaciu C. (2015). Thermal stability study of the grape seeds extracts in the aqueous solutions. Bulletin UASVM Food Science and Technology, 72, 1.

[38] Cristea E. (2016). The influence of thermal treatments on the antioxidant activity and colour of chokeberry (Aronia menocarpa) extract. International Journal of Food Studies, 5(2).

[39] Lee D and Kim CY. (2017). Influence of roasting treatment on the antioxidant activities and color of burdock root tea. Preventive Nutrition and Food Science, 22(1), 21.

[40] Murakami M, Yamaguchi T, Takamura H and Atoba TM. (2004). Effects of thermal treatment on radicalscavenging activity of single and mixed polyphenolic compounds. Journal of Food Science, 69(1), FCT7-FCT10.

[41] Chuah AM, Lee YC, Yamaguchi T, Takamura H, Yin LJ and Matoba T. (2008). Effect of cooking on the antioxidant properties of coloured peppers. Food Chemistry, 111(1), 20-28.

\section{How to cite this article}

Muhamad S and Mat Ali SFZ. (2019). Boiling increase antioxidant activity, total phenolic content and total flavonoid content in Plectranthus amboinicus leaves. GSC Biological and Pharmaceutical Sciences, 6(3), 24-30. 